\title{
Volume expansion and vasodilators in the treatment of idiopathic postural hypotension
}

\author{
D. H. JONES \\ M.D., M.Sc., M.R.C.P. \\ J. L. REID \\ D.M., M.R.C.P.
}

\section{Department of Clinical Pharmacology, Royal Postgraduate Medical School, Hammersmith Hospital, Du Cane Road, London W12 OHS}

\begin{abstract}
Summary
A case is cited in which hydrallazine was used in conjunction with volume expansion as a novel approach to the improvement of orthostatic symptoms in a patient with idiopathic postural hypotension.
\end{abstract}

\section{Introduction}

Postural hypotension, whether isolated or associated with other neurological symptoms, such as the Shy-Drager syndrome, is a severely incapacitating and distressing condition. Therapy remains unsatisfactory and includes antigravity devices, $\alpha$ adrenoceptor agonists with or without monoamine oxidase inhibitors, and volume expansion with mineralocorticoids. Recent reports have indicated an unpredictable response to tyramine with monoamine oxidase inhibitors, and the hazard of iatrogenic supine hypertension (Nanda, Johnson and Keogh, 1976; Davies, Bannister and Sever, 1978). A case is cited to illustrate the use of a therapeutic regime including the vasodilator hydrallazine which has provided subjective improvement in symptoms and objective evidence of enhanced orthostatic tolerance.

\section{Case report}

A 70-year-old man had experienced postural dizziness and blackouts for 4 years, and his BP had shown a marked postural drop with no change in heart rate. His therapy included elastic stockings, and oral administration of ephedrine and sustained release isoprenaline. There was no improvement in symptoms and signs; administration of fludrocortisone resulted in severe hypokalaemia (serum potassium $2.2 \mathrm{mmol} / \mathrm{l})$. His symptoms became progressively worse and he was unable to leave his bed. Before investigation he had had several episodes of transient right hemipareses on standing. Severe morning headaches were experienced in the supine posture and dizziness and syncope occurred on standing. The addition of sodium supplements caused peripheral oedema and exacerbated the $\frac{0}{3}$ supine hypertension.

Investigations showed no aetiology for the postural hypotension, but confirmed impaired cardiovascular reflexes (absent heart rate and pressor response to $\dot{\tilde{N}}$ Valsalva's manoeuvre, cold pressor test, mental ${ }_{+}^{\omega}$ arithmetic and isometric handgrip exercise). Adreno-o cortical function was normal. Urinary catecholamine excretion was low at $8 \cdot 1 \mu \mathrm{g} / \mathrm{g}$ creatinine (normal $>$ range 19-54); plasma noradrenaline was also extremely low at $0.05 \mu \mathrm{g} / \mathrm{l}$ (normal range $0.07-0.70$ ) $\vec{\circ}$ and did not rise on $70^{\circ}$ head up tilt. Pressor sensitivio ${ }^{\circ}$ to i.v. noradrenaline $(0.016 \mu \mathrm{g} / \mathrm{kg} / \mathrm{min}$ raised systolic BP by $60 \mathrm{mmHg}$ ) was markedly increased: Intravenous atropine to a total dose of $2.4 \mathrm{mg}$ failed to raise the heart rate above 64 beats/min.

Three therapeutic regimes were given to the $\stackrel{2}{\circ}$ patient in a single-blind manner. The patient $\stackrel{\varnothing}{\mathscr{}}$ continued to take $0.05 \mathrm{mg}$ fludrocortisone and $\overrightarrow{\vec{O}}$ sodium chloride $(80 \mathrm{mmol}$ of sodium daily) in 3 unchanged doses throughout the studies. The regimes comprised: (1) placebo; (2) $10 \mathrm{mg}$ tyramine orally‥ after pretreatment for 6 days with phenelzine $45 \mathrm{mg}$ 을 daily; and (3) hydrallazine $75 \mathrm{mg}$ daily orally. Hourly measurements of pulse and BP were made following a morning dose of drug.

Tyramine and monoamine oxidase inhibition 0 produced no improvement in orthostatic tolerance. $₹$ Hydrallazine caused a small fall in the supine press-음 ure and produced a small rise in the standing BP; it also caused an increase in the heart rate in both lying and standing positions. The BP and pulse rateN are shown in the table.

The patient continued to wear elastic stockings 0 during his stay in, and following discharge from, $\mathbb{E}$ hospital. His drug therapy on discharge comprised fludrocortisone $0.05 \mathrm{mg}$ daily, sustained releaseco sodium chloride, and hydrallazine $75 \mathrm{mg}$ daily. $\mathbb{\Phi}$ When reassessed 4 months later on the same regime, $\stackrel{?}{+}$ he had not experienced any further episodes of loss? of consciousness, and was able to walk in and $\underset{\mathbb{D}}{\circ}$ around his home. His BP and heart rate were 
TABLE 1. Mean values of hourly BP and pulse recordings over a 6-hr period following drug administration

\begin{tabular}{|c|c|c|c|}
\hline & Placebo & $\begin{array}{l}\text { Tyramine }+ \text { monoamine } \\
\text { oxidase inhibitor }\end{array}$ & Hydrallazine \\
\hline $\begin{array}{l}\text { Supine } \\
\text { BP (mmHg) } \\
\text { pulse rate (beats/min) }\end{array}$ & $\begin{array}{c}170 / 103 \\
55\end{array}$ & $\begin{array}{c}151 / 95 \\
59\end{array}$ & $\begin{array}{c}159 / 87^{* *} \\
69^{* * *}\end{array}$ \\
\hline $\begin{array}{l}\text { Standing } \\
\text { BP } \\
\text { pulse rate }\end{array}$ & $\begin{array}{c}97 / 64 \\
60\end{array}$ & $\begin{array}{c}82 / 62 \\
61\end{array}$ & $\begin{array}{c}102 / 72^{*} \\
65^{*}\end{array}$ \\
\hline
\end{tabular}

unchanged from the recordings on hydrallazine in hospital.

Nine months following the patient's initial investigations he was readmitted to hospital for review of therapy and for single-blind substitution of the hydrallazine with placebo. On admission he was able to assume the standing position and to walk around without symptoms. Within $24 \mathrm{hr}$ of placebo substitution, he experienced supine and postural headaches, and became weak and light-headed on standing and walking.

In view of favourable reports by Kochar and Itskovitz (1978) on the use of indomethacin in this condition, a trial of this drug in a dose of $100 \mathrm{mg}$ daily was conducted. Tilt table measurements were attempted after $48 \mathrm{hr}$ 's treatment with indomethacin, but had to be abandoned because of severe postural symptoms and unrecordable BP after only one minute at a $35^{\circ}$ tilt.

The patient was restarted on hydrallazine $100 \mathrm{mg}$ daily. Within $24 \mathrm{hr}$ his symptoms had improved, and by $48 \mathrm{hr}$ he was able to walk around without postural symptoms.

\section{Comment}

Therapy in idiopathic postural hypotension has been directed towards increasing cardiac output by chronotropic agents, or by influencing the effective circulating volume by means of arteriolar constriction and/or volume expansion. These manoeuvres result in minimal subjective and objective improvement-and often exacerbate the not infrequent supine hypertension. The present case study investigates a novel approach to improve orthostatic tolerance-involving volume expansion in association with a reduction in cardiac afterload effected by a decrease in arteriolar resistance. Cohn and Franciosa (1977) have described hydrallazine as producing its effect almost exclusively in the arterial bed; in the patient described, therefore, the reduced cardiac afterload, in conjunction with the increase in circulating volume produced by sodium supplementation and fluorocortisone, presumably results in improved cardiac output-but without producing supine hypertension. As a result of this increased output, venous return is increased, so that the tendency to a postural fall in BP is reduced. Hydrallazine (unlike some other vasodilators) does not cause venodilatation, and therefore does not have any adverse effect on cardiac preload. This indication for arteriolar vasodilator therapy is analogous to the role of vasodilators in the management of cardiac failure (Cohn and Franciosa, 1977).

This single-blind, crossover hospital study resulted in subjective and objective patient improvement which was maintained during longer term outpatient management. Further controlled trials of this regime are therefore indicated.

\section{Acknowledgments}

The patient was referred to Hammersmith Hospital by Dr Richard Wray; invaluable technical and nursing assistance was provided throughout the studies by Mrs Julia Daniel.

\section{References}

Cohn, J.N. \& Franciosa, J.A. (1977) Drug therapy: vasodilator therapy of cardiac failure. New England Journal of Medicine, 297, 27, 254.

Davies, B., Bannister, R. \& Sever, P. (1978) Pressor amines and monoamine oxidase inhibitors for treatment of postural hypotension in autonomic failure-limitations and hazards. Lancet, i, 172.

KochaR, M.S. \& ITSKovitz, H.D. (1978) Treatment of idiopathic orthostatic hypotension (Shy-Drager syndrome) with indomethacin. Lancet, $\mathbf{i}, 1011$.

NANDA, R.N., Johnson, R.H. \& KeOGh, H.J. (1976) Treatment of neurogenic orthostatic hypotension with a monoamine oxidase inhibitor and tyramine. Lancet, ii, 1164. 